\title{
Psychological reactions to COVID-19 and epidemiological aspects of dental practitioners during lockdown in Italy
}

\author{
Pierantonio BELLINI 1, Vittorio CHECCHI ${ }^{*}$ *, Cristina IANI 2 , \\ Davide BENCIVENNI ${ }^{1}$, Ugo CONSOLO ${ }^{1}$
}

\begin{abstract}
${ }^{1}$ Unit of Dentistry and Oral Maxillo-Facial Surgery, Department of Surgery, Medicine, Dentistry and Morphological Sciences with Transplant Surgery, Oncology and Regenerative Medicine Relevance, University of Modena and Reggio Emilia, Modena, Italy; 2Department of Surgery, Medicine, Dentistry and Morphological Sciences with Transplant Surgery, Oncology and Regenerative Medicine, Relevance-Center for Neuroscience and Neurotechnology, University of Modena and Reggio Emilia, Modena, Italy
\end{abstract}

*Corresponding author: Vittorio Checchi, Unit of Dentistry and Oral Maxillo-Facial Surgery, Department of Surgery, Medicine, Dentistry and Morphological Sciences with Transplant Surgery, Oncology and Regenerative Medicine Relevance, University of Modena and Reggio Emilia, Via del Pozzo 71, 41100 Modena, Italy. E-mail: vittorio.checchi@unimore.it

\section{A B S T R A C T}

BACKGROUND: Due to droplet production and exposure to saliva and blood, dental practitioners are at high risk of COVID-19 contagion during their routine procedures. The aim of this study was to investigate the behavior of Italian dentists and to analyze their reactions in relation to Sars-CoV-2 pandemic professional restrictive measures.

METHODS: An online structured survey composed of 40 questions has been sent to dental practitioners all over Italy to investigate their behavior and to analyze their reactions in relation to Sars-CoV-2 pandemic restrictive measures introduced by the Italian national administrative order of 10 March 2020 (DM-10M20).

RESULTS: 1109 dentists replied. To assess concerns and psychological responses the sample was divided into two groups based on the number of cases registered in their work area. In the first group were included all the responders working in the Italian regions that had more than 15,000 confirmed cases of COVID-19 as of April 29, 2020. The second group included responders working in the Italian regions that had less than 15,000 confirmed cases. The $45.2 \%$ of the respondents showed minimal anxiety, $34.5 \%$ showed mild anxiety, $13.9 \%$ showed moderate anxiety, while $6.4 \%$ showed a score indicative of a severe level of anxiety.

CONCLUSIONS: The COVID-19-related emergency condition had a highly negative impact on dental practices in Italy. Those who completed the survey reported practice closure or reduction during the lockdown, and a high level of concern about the professional future for all dental practitioners. Concerns related to professional activity were accompanied by severe anxiety levels.

(Cite this article as: Bellini P, Checchi V, Iani C, Bencivenni D, Consolo U. Psychological reactions to COVID-19 and epidemiological aspects of dental practitioners during lockdown in Italy. Minerva Dent Oral Sc 2021;70:32-43. DOI: 10.23736/ S2724-6329.20.04430-1)

KEY wORDS: COVID-19; Severe acute respiratory syndrome Coronavirus 2; Epidemiology; Anxiety; Surveys and questionnaires.

$\mathrm{Y}$ ear 2020 will be remembered as the year of the world pandemic caused by Coronavirus disease 19 (COVID-19). This highly infective Coronavirus, named severe acute respiratory syndrome - Coronavirus - 2 (Sars-CoV-2), is a new virus responsible of an acute respiratory syndrome, often asymptomatic but potentially lethal.1, 2 This virus is transmitted through micro- and macro-droplets, and diffusion mainly occurs through exhalation, sneezing, coughing 


\section{COPYRIGHT $^{\circledR} 2021$ EDIZIONI MINERVA MEDICA}

and saliva. Droplets $>5 \mu \mathrm{m}$ in diameter can reach 1 meter, whereas droplets $<5 \mu \mathrm{m}$ are grouped in aerosol that can reach distances well above 1 meter. ${ }^{3,4}$

Based on data retrieved from the World Health Organization (WHO), at the date of the present article (June 13, 2020), there have been $7,553,182$ confirmed cases of Coronavirus infected patients worldwide, and 423,349 cases of deaths. From February 21, 2020, Italy has seen a quick and massive diffusion of COVID-19 and in mid-June showed 236,305 COVID-19 cases, with 34,223 deaths. ${ }^{5}$

Health care workers certainly are the category with the highest diffusion of the contagion, and due to droplet production and exposure to saliva and blood, dental practitioners are at high risk of contagion during their routine procedures. ${ }^{6}$ SARS-CoV-2 transmission during dental procedures can occur through direct contact with mucous membranes, oral fluids and contaminated instruments and surfaces, or the inhalation of aerosol/droplets from infected individuals. ${ }^{2,4}$

In a previously published study, it has been shown that the $85 \%$ of dentists from one of the most affected Italian area reported being extremely worried of contracting the infection during their clinical activity. Moreover, $9 \%$ of them showed severe levels of anxiety, demonstrating that COVID-19 emergency had a highly negative impact on their activity. ${ }^{7}$

The aim of this study was to investigate the behavior of dentists from different parts of Italy and to analyze their reactions in relation to SarsCoV-2 pandemic professional restrictive measures due to Italian national administrative order of 10 March 2020 (DM-10M20).

\section{Materials and methods}

An online structured survey composed of 40 questions has been sent to dental practitioners all over Italy to investigate their behavior and to analyze their reactions in relation to Sars-CoV-2 pandemic restrictive measures introduced by the Italian national administrative order of March 10, 2020 (DM-10M20). Data collection took place in the time period from April 2 to April 29, 2020.

The survey was created using the free-access
Google Forms application and the link to the online survey was sent through an anonymous mailing list. At the beginning of the survey participants were informed that their participation was voluntary, their responses were anonymous, and that they could drop out at any time. Then they were explicitly asked if they wanted to participate in the research study before starting the survey.

The structured survey was composed of 40 questions, divided into five sections (Table I).

The first part of the questions collected demographic data (age and gender), the level of work experience and the type of activity carried out by the interviewees. The second section assessed whether the professionals closed their dental practice or reduced their clinical activity following the outbreak of the emergency, and whether this occurred before or after the restrictive measures introduced by the Italian government in 10 March 2020 (DM-10M20); which modalities were used to inform patients; and whether patients understood the reasons for the closure/activity reduction. The third section was composed of questions investigating the impact of the COVID-19 outbreak on dental practice: questions regarding the most common protective personal equipment (PPE), their retrieval and use before, during and after COVID-19 outbreak. The fourth group of questions assessed practitioners' direct or indirect contact with COVID-19, the feelings and emotions experienced while thinking at the COVID-19 outbreak, the dentists' perception of infection likelihood for themselves and patients. Questions taken from the generalized anxiety disorder 7-item (GAD-7) scale ${ }^{8}$ were also included to assess the presence of general anxiety symptoms. The questions assessed whether in the previous two weeks responders had been bothered by: 1) feeling nervous, anxious, or on edge; 2) being unable to stop or control worrying; 3 ) worrying too much about different things; 4) experiencing difficulties in relaxing; 5) being restless; 6) becoming easily annoyed or irritable; and 7) feeling afraid as if something awful might happen. The fifth and final section of the survey assessed the dentists' main concerns about the professional future, what measures they consider use- 


\section{COPYRIGHT $^{\circledR} 2021$ EDIZIONI MINERVA MEDICA}

BELLINI

DENTISTS REACTIONS DURING COVID-19 LOCKDOWN

TABLE I.-Survey composed of 40 questions that has been sent in order to investigate dentist behavior and to analyze their reactions in relation to COVID-19 pandemic restrictive measures.

\begin{tabular}{|c|c|}
\hline Question & Answer(s) \\
\hline \multirow[t]{2}{*}{ 1. Do you want to participate in this survey? } & Yes \\
\hline & No \\
\hline \multirow[t]{3}{*}{ 2. Age } & $<35$ year \\
\hline & $35-55$ year \\
\hline & $>55$ year \\
\hline \multirow[t]{2}{*}{ 3. Sex } & Male \\
\hline & Female \\
\hline \multirow{3}{*}{$\begin{array}{l}\text { 4. Dental practice in } \\
\text { [One answer allowed] }\end{array}$} & Modena \\
\hline & Reggio Emilia \\
\hline & Other (specify) \\
\hline \multirow{4}{*}{$\begin{array}{l}\text { 5. Professional experience } \\
\text { [One answer allowed] }\end{array}$} & $0-5$ years \\
\hline & $6-10$ years \\
\hline & $11-15$ years \\
\hline & $>15$ years \\
\hline \multirow{3}{*}{$\begin{array}{l}\text { 6. Professional setting } \\
\text { [One answer allowed] }\end{array}$} & Owner of private practice \\
\hline & $\begin{array}{l}\text { Partner or employed in private } \\
\text { practice }\end{array}$ \\
\hline & Employed in public structure \\
\hline \multirow{2}{*}{$\begin{array}{l}\text { 7. Number of dental chairs } \\
\text { [One answer allowed] }\end{array}$} & One \\
\hline & $\begin{array}{l}\text { Two/Three } \\
>\text { Three }\end{array}$ \\
\hline \multirow{2}{*}{$\begin{array}{l}\text { 8. Number of dental assistants and/or secretaries } \\
\text { [One answer allowed] }\end{array}$} & One \\
\hline & $\begin{array}{l}\text { Two/Three } \\
\text { >Three }\end{array}$ \\
\hline \multirow{2}{*}{$\begin{array}{l}\text { 9. Number of partners or employees } \\
\text { [One answer allowed] }\end{array}$} & None \\
\hline & $\begin{array}{l}\text { One } \\
>\text { One }\end{array}$ \\
\hline \multirow{4}{*}{$\begin{array}{l}\text { 10. Weekly average working time } \\
\text { [One answer allowed] }\end{array}$} & $<20 \mathrm{~h}$ \\
\hline & $20-30 \mathrm{~h}$ \\
\hline & $30-40 \mathrm{~h}$ \\
\hline & $>40 \mathrm{~h}$ \\
\hline \multicolumn{2}{|l|}{$\begin{array}{l}\text { 11. Average number of patients treated daily before Italian national administrative order } \\
\text { of } 10 \text { March } 2020 \text { (DM-10M20) }\end{array}$} \\
\hline \multirow{2}{*}{$\begin{array}{l}\text { 12. Due to Coronavirus disease } 19 \text { (COVID-19), was the practice closed/reduced to } \\
\text { urgent procedures only? } \\
\text { [One answer allowed] }\end{array}$} & Yes \\
\hline & No \\
\hline \multirow{2}{*}{$\begin{array}{l}\text { 13. When was the practice close or clinical activity reduced to urgent procedures only? } \\
\text { [One answer allowed] }\end{array}$} & Before DM-10M20 \\
\hline & After DM-10M20 \\
\hline \multirow{2}{*}{$\begin{array}{l}\text { 14. A telephonic availability was guaranteed for dental emergencies? } \\
\text { [One answer allowed] }\end{array}$} & Yes \\
\hline & No \\
\hline \multirow{2}{*}{$\begin{array}{l}\text { 15. In case of dental emergencies, did you personally take care of them? } \\
\text { [One answer allowed] }\end{array}$} & Yes \\
\hline & No \\
\hline \multirow{2}{*}{$\begin{array}{l}\text { 16. In case of dental emergencies, were the dental assistant(s) present? } \\
\text { [One answer allowed] }\end{array}$} & Yes \\
\hline & No \\
\hline \multirow{2}{*}{$\begin{array}{l}\text { 17. Did patients understand motivations for practice closure/clinical activity reduction? } \\
\text { [One answer allowed] }\end{array}$} & Yes \\
\hline & No \\
\hline \multirow{4}{*}{$\begin{array}{l}\text { 18. How were patients notified of practice closure/clinical activity reduction? } \\
\text { [Multiple answers allowed] }\end{array}$} & By telephone \\
\hline & By email \\
\hline & By web site \\
\hline & $\begin{array}{l}\text { By social networks (Facebook, } \\
\text { Instagram, etc.) }\end{array}$ \\
\hline \multicolumn{2}{|l|}{ 19. Average number of patients treated daily after DM-10M20 } \\
\hline \multirow{7}{*}{$\begin{array}{l}\text { 20. Did patients cancel their previously taken appointments after DM-10M20? } \\
\text { [One answer allowed] } \\
\text { 21. Did COVID-19 pandemic condition negatively your professional activity? } \\
\text { [One answer allowed] }\end{array}$} & Yes \\
\hline & No \\
\hline & Not at all \\
\hline & Little \\
\hline & Quite \\
\hline & A lot \\
\hline & Extremely \\
\hline
\end{tabular}

(To be continued) 


\section{COPYRIGHT $^{\odot} 2021$ EDIZIONI MINERVA MEDICA}

TABLE I.-Survey composed of 40 questions that has been sent in order to investigate dentist behavior and to analyze their reactions in relation to COVID-19 pandemic restrictive measures (continues).

\begin{tabular}{|c|c|}
\hline Question & Answer(s) \\
\hline $\begin{array}{l}\text { 22. Which personal protective equipment (PPE) were used usually before COVID-19? } \\
\text { [One answer allowed] }\end{array}$ & $\begin{array}{l}\text { Gloves and surgical masks } \\
\text { Gloves, surgical masks and } \\
\text { disposable isolation gowns } \\
\text { Gloves, surgical masks, disposable } \\
\text { isolation gowns, disposable } \\
\text { protective cap and glasses/face } \\
\text { shield } \\
\text { Others (specify) }\end{array}$ \\
\hline $\begin{array}{l}\text { 23. Since DM-10M20, did you modify the choice of PPE? } \\
\text { [One answer allowed] }\end{array}$ & $\begin{array}{l}\text { Yes } \\
\text { No } \\
\text { No, I am waiting government } \\
\text { guidelines }\end{array}$ \\
\hline $\begin{array}{l}\text { 24. Since DM-10M20, did you hold informative sessions dedicated to coworkers and } \\
\text { employees on the correct use of PPE? } \\
\text { [One answer allowed] }\end{array}$ & $\begin{array}{l}\text { Yes } \\
\text { No } \\
\text { No, but I will do it }\end{array}$ \\
\hline $\begin{array}{l}\text { 25. Dental associations had been useful in giving instructions about PPE? } \\
\text { [One answer allowed] }\end{array}$ & $\begin{array}{l}\text { Yes } \\
\text { No } \\
\text { I do not know }\end{array}$ \\
\hline $\begin{array}{l}\text { 26. During clinical activity, which measures do you use to prevent COVID-19 infection? } \\
\text { [Multiple answers allowed] }\end{array}$ & $\begin{array}{l}\text { Telephone screening/anamnesis } \\
\text { to exclude COVID-19 related } \\
\text { symptoms } \\
\text { Telephone screening/anamnesis to } \\
\text { identify possible critical cases } \\
\text { Reduction of number of patients in } \\
\text { the waiting room } \\
\text { Body temperature measurement } \\
\text { Environment aeration } \\
\text { Environment sanitation } \\
\text { Disinfectant agents and surgical } \\
\text { mask supply to all patients while } \\
\text { waiting in waiting room } \\
\text { Use of PPE (Respirator masks, } \\
\text { disposable gowns, double layered } \\
\text { gloves, etc.) } \\
\text { Other (specify) }\end{array}$ \\
\hline $\begin{array}{l}\text { 27. Since the beginning of the pandemic, did you have difficulties in finding PPE? } \\
\text { [One answer allowed] }\end{array}$ & $\begin{array}{l}\text { Yes } \\
\text { No } \\
\text { I do not know }\end{array}$ \\
\hline $\begin{array}{l}\text { 28. Since the beginning of the pandemic, have you noticed delays in the delivery timing } \\
\text { of dental materials? } \\
\text { [One answer allowed] }\end{array}$ & $\begin{array}{l}\text { Yes } \\
\text { No } \\
\text { I don't know }\end{array}$ \\
\hline $\begin{array}{l}\text { 29. Do you know someone who contracted COVID-19? } \\
\text { [Multiple answers allowed] }\end{array}$ & $\begin{array}{l}\text { Me } \\
\text { One or more relatives } \\
\text { On or more employees } \\
\text { One or more patients } \\
\text { One or more acquaintances } \\
\text { No }\end{array}$ \\
\hline $\begin{array}{l}\text { 30. How worried are you of contracting COVID-19 during your clinical activity? } \\
\text { [One answer allowed] }\end{array}$ & $\begin{array}{l}\text { Not at all } \\
\text { Little } \\
\text { Quite } \\
\text { A lot } \\
\text { Extremely }\end{array}$ \\
\hline $\begin{array}{l}\text { 31. In your opinion, how likely is it that a patient can contract COVID-19 during a dental } \\
\text { service? } \\
\text { [One answer allowed] }\end{array}$ & $\begin{array}{l}\text { Not at all } \\
\text { Little } \\
\text { Quite } \\
\text { A lot } \\
\text { Extremely }\end{array}$ \\
\hline
\end{tabular}




\section{COPYRIGHT $^{\circledR} 2021$ EDIZIONI MINERVA MEDICA}

BELLINI

DENTISTS REACTIONS DURING COVID-19 LOCKDOWN

TABLE I.-Survey composed of 40 questions that has been sent in order to investigate dentist behavior and to analyze their reactions in relation to COVID-19 pandemic restrictive measures (continues).

\begin{tabular}{|c|c|c|c|c|}
\hline Question & \multicolumn{4}{|c|}{ Answer(s) } \\
\hline $\begin{array}{l}\text { 32. How much do you think your patients are worried of contracting COVID-19 during a } \\
\text { dental service? } \\
\text { [One answer allowed] }\end{array}$ & $\begin{array}{l}\text { Not at all } \\
\text { Little } \\
\text { Quite } \\
\text { A lot } \\
\text { Extremel }\end{array}$ & & & \\
\hline 33. Which of the following emotions do you feel when thinking about COVID-19? & $\begin{array}{l}\text { Fear } \\
\text { Anxiety } \\
\text { Concern } \\
\text { Sadness } \\
\text { Anger }\end{array}$ & & & \\
\hline 34. How frequently one of these issues bothered you in the past two weeks? & $\begin{array}{l}\text { Not at } \\
\text { all }\end{array}$ & $\begin{array}{c}\text { Several } \\
\text { days }\end{array}$ & $\begin{array}{l}\text { More } \\
\text { than } \\
\text { half the } \\
\text { days }\end{array}$ & $\begin{array}{l}\text { Nearly } \\
\text { every } \\
\text { day }\end{array}$ \\
\hline
\end{tabular}

Being more nervous and/or anxious

Being unable to stop worrying

Being too much worried for various things

Having difficulties in relaxing

Being agitated and unable to stay still

Getting easily irritated

Having fear that something terrible could happen

35 . How worried are you for your professional future?

[One answer allowed]

Not at all

Little

Quite

A lot

36. What worries you the most?

[Multiple answers allowed]

Extremely

I do not know when this emergency situation will end

Patients will have less money to spend

The crisis of dental environments will get worse

The need of new procedures and new devices for safety and infection prevention

The chance of losing my job or having to fire my employees

37. Which aids do you think could help dental professionals during COVID-19 pandemic?

[Multiple answers allowed]

Economic relieves from Italian government

Improvement of communication with patients

Economic relieves from dental associations

Bank account support

Social security institutions support and subsidy

38. Which aids do you think could help dental professionals after COVID-19 pandemic?

Economic relieve

[Multiple answers allowed] government

Improvement of communication with patients

Economic relieves from dental associations

Bank account support

Social security institutions support and subsidy 


\section{COPYRIGHT $^{\circledR} 2021$ EDIZIONI MINERVA MEDICA}

TABLE I.-Survey composed of 40 questions that has been sent in order to investigate dentist behavior and to analyze their reactions in relation to COVID-19 pandemic restrictive measures (continues).

\begin{tabular}{|c|c|}
\hline Question & Answer(s) \\
\hline $\begin{array}{l}\text { 39. During clinical activity, which measures will you use to prevent COVID-19 } \\
\text { infection? } \\
\text { [Multiple answers allowed] }\end{array}$ & $\begin{array}{l}\text { Telephone screening/anamnesis to } \\
\text { identify possible critical cases } \\
\text { Reduction of number of patients in } \\
\text { the waiting room } \\
\text { Body temperature measurement } \\
\text { Environment aeration } \\
\text { Environment sanitation } \\
\text { Disinfectant agents and surgical } \\
\text { mask supply to all patients while } \\
\text { waiting in waiting room } \\
\text { Use of PPE (Respirator masks, } \\
\text { disposable gowns, double layered } \\
\text { gloves, etc.) } \\
\text { Other (specify) } \\
\text { Prevention procedures } \\
\text { standardization }\end{array}$ \\
\hline $\begin{array}{l}\text { 40. Which improvements do you think can result from the COVID-19 emergency? } \\
\text { [Multiple answers allowed] }\end{array}$ & $\begin{array}{l}\text { Reduction of dental practices } \\
\text { competition } \\
\text { Improvement of communication with } \\
\text { patients } \\
\text { Professional rhythm slowdown } \\
\text { Stabilization of relationship with } \\
\text { dental associations } \\
\text { No improvements }\end{array}$ \\
\hline
\end{tabular}

ful to support professionals during and after the emergency and whether they believed that the emergency situation could lead to improvements.

\section{Results}

One thousand one hundred and nine dentists replied to the survey. For each question, we computed the percentage of respondents that gave a particular answer with respect to the number of total responses to the questions.

Of the total responders, $29.6 \%(\mathrm{~N} .=328)$ were females, $70.4 \%(\mathrm{~N} .=781)$ were males. The majority of them were aged between 35 and 55 $(44.3 \%), 39.7 \%$ were over 55 years old, while only $16.0 \%$ of them were under 35 years old. Therefore, most had been working for more than 15 years $(68.8 \%), 21.2 \%$ had been working for 6-14 years, while $10 \%$ had been working for less than 5 years. The majority of the compilers $(820$, $74 \%$ ) reported working $30-40 \mathrm{~h}$ or more per week, while the remaining 289 (26\%) reported working less than $30 \mathrm{~h}$ per week. A large number of dentists were practice owners $(70.2 \%)$, while the others were private $(27.4 \%)$ or public $(2.3 \%)$ structures employees (Table II).

The majority of the respondents $(1102,99.4 \%)$ closed or highly reduced their activity to urgent procedures, $41.2 \%$ before and $58.8 \%$ after the DM-10M20; only 7 professionals said they did not close the business. A high percentage of patients $(88.9 \%)$ cancelled their previously-taken appointments after the DPCM-10M20. Patients were contacted by phone $(92.3 \%)$, only $6.5 \%$ through social channels or websites and a limited number by e-mail (1.2\%). Most of them understood the reasons for the closure of dental practices or for the reduction in clinical activity. A large number of dentists $(1075,97.5 \%)$ guaranteed telephone availability for dental emergencies and for this reason a high percentage reported going personally to the office $(1011,91.7 \%)$. In case of dental emergencies, $51.7 \%$ of respondents took care of it alone, and $48.3 \%$ of them were helped by an assistant.

Each practitioner asserted a routinely use of the most common protective personal equipment (PPE), such as gloves, masks, disposable gowns, and protective glasses before the SARS-CoV-2 


\section{COPYRIGHT $^{\circledR} 2021$ EDIZIONI MINERVA MEDICA}

BELLINI

DENTISTS REACTIONS DURING COVID-19 LOCKDOWN

TABLE II.-Demographic information of dental practitioners (total $=1109)$.

\begin{tabular}{llc}
\hline Demographics & & Number (\%) \\
\hline Gender & Male & $781(70.4)$ \\
& Female & $328(29.6)$ \\
Age (years) & Less than 35 & $177(16)$ \\
& $35-55$ & $491(44.3)$ \\
Type of activity & Above 55 & $441(39.7)$ \\
& Practice owner & $779(70.2)$ \\
Work experience (years) & Private practice employee & $304(27.4)$ \\
& Public structure employee & $26(2.3)$ \\
& $0-5$ & $111(10)$ \\
Numbers of hours worked per week & $6-10$ & $115(10.4)$ \\
& $11-15$ & $120(10.8)$ \\
& More than 15 & $763(68.8)$ \\
& Less than 20 & $64(5.8)$ \\
& $20-30$ & $225(20.3)$ \\
\hline
\end{tabular}

pandemic. The $74.5 \%$ of dentists replied that they had changed the type of PPE used during the pandemic by COVID-19, or in any case that they were waiting for directives to do so (18.8\%); only $6.8 \%$ have not changed their PPE. Most of the interviewees $(769,69.3 \%)$ report having held information sessions dedicated to the staff on the correct use of PPE, $20 \%$ said that they will soon, but $10.6 \%$ did not.

Since the start of the COVID-19 lockdown, $86.2 \%$ of respondents have encountered difficulties in finding PPE and $62.5 \%$ have encountered problems in the delivery time of dental materials.

Only seventeen (1.5\%) respondents contracted COVID-19, while $27.4 \%$ did not know anyone who has contracted the disease. In total, $77.8 \%$ knew at least one person who has been infected (relatives, employees, acquaintances, patients).

Given the different distribution of the COVID-19 pandemic in the Italian regions, to assess concerns and psychological responses we divided the sample into two groups based on the number of cases registered in their work area. In the first group we included all the responders working in the Italian regions that had more than 15,000 confirmed cases of COVID-19 as of April 29, 2020.9 These regions were Lombardy, Emilia-Romagna, Piedmont and Veneto and the responders working in these regions were 828 . The second group included responders working in all the other Italian regions, that had less than
15,000 confirmed cases. This group was composed of 281 responders.

Overall, for $71.1 \%$ of the respondents, COVID-19 was having an extremely negative impact on their professional activity and the majority of them was quite $(41.1 \%)$ or a lot $(25.8 \%)$ concerned about the professional future, mostly due to the uncertainty about the end of the emergency situation $(54.0 \%)$ and people's reduced spending capacity $(41.5 \%)$. These percentages were quite similar in the two groups. Indeed, the impact was judged as extreme by $71.9 \%$ of dentists in the first group and by $68.7 \%$ of dentists in the second group.

Dentists reported being from moderately $(39.0 \%)$ to highly $(24.3 \%)$ concerned of contracting COVID-19 during their clinical activity. Only $3.4 \%$ were not concerned at all. $40.1 \%$ of them believed patients' concern of contracting the infection during a dental visit was moderate, even though $45.8 \%$ of them considered the patient's likelihood of infection as low. For these questions, response categories were assigned a score ranging from 0 to $4(0=$ "not at all;" $4=$ "extremely") and a $t$-test for independent samples was performed on these recoded values. Results of the comparisons between the two groups regarding these questions showed no significant difference (all ps $>0.14$ ) (Table III).

When thinking about COVID-19, only $10.4 \%$ of the respondents reported to experience fear intensely, while the majority reported to feel 


\section{COPYRIGHT $^{\odot} 2021$ EDIZIONI MINERVA MEDICA}

DENTISTS REACTIONS DURING COVID-19 LOCKDOWN

BELLINI

TABLE III.-Dentists' concern of contracting COVID-19, perception of the infection likelihood for patients and level of concern attributed to patients for the two groups.

\begin{tabular}{|c|c|c|c|c|c|c|}
\hline Question & Group & $\begin{array}{l}\text { Not at all } \\
\text { N. }(\%)\end{array}$ & $\begin{array}{l}\text { Little } \\
\text { N. }(\%)\end{array}$ & $\begin{array}{l}\text { Quite } \\
\text { N. }(\%)\end{array}$ & $\begin{array}{l}\text { A lot } \\
\text { N. }(\%)\end{array}$ & $\begin{array}{l}\text { Extremely } \\
\text { N. (\%) }\end{array}$ \\
\hline How worried are you of contracting & 1 & $28(3.4)$ & $156(18.8)$ & $320(38.6)$ & $206(24.9)$ & $118(14.3)$ \\
\hline COVID-19 during your clinical practice? & 2 & $10(3.6)$ & $56(19.9)$ & $112(39.9)$ & $64(22.8)$ & $39(13.9)$ \\
\hline In your opinion, how likely is it that a & 1 & $200(24.2)$ & $364(44.0)$ & $169(20.4)$ & $65(7.9)$ & $30(3.6)$ \\
\hline $\begin{array}{l}\text { patient can contract COVID-19 during a } \\
\text { dental service? }\end{array}$ & 2 & $58(20.6)$ & $144(51.2)$ & $45(16.0)$ & $27(9.6)$ & $7(2.5)$ \\
\hline How much do you think patients are & 1 & $69(8.3)$ & $210(25.4)$ & $338(40.8)$ & $182(22.0)$ & $29(3.5)$ \\
\hline $\begin{array}{l}\text { worried of contracting COVID-19 during } \\
\text { a dental procedure? }\end{array}$ & 2 & $9(3.2)$ & $84(29.9)$ & $107(38.1)$ & $69(24.6)$ & $12(4.3)$ \\
\hline
\end{tabular}

lightly $(37.7 \%)$ or moderately $(24.3 \%)$ scared. Only $14.5 \%$ reported to experience anxiety intensely, while $33.1 \%$ reported to feel lightly and $22.6 \%$ moderately anxious. Only $23.6 \%$ reported to experience concern intensely, while the majority reported levels of concern ranging from light $(27.6 \%)$ to moderate $(30.0 \%)$. Only $17.2 \%$ of respondents felt intensely sad, while $23.5 \%$ did not experience sadness at all. Anger was experienced in an intense way by only $12.0 \%$ of respondents, while $39.7 \%$ of respondents did not experience anger at all. For the questions assessing the emotions experienced when thinking about COVID-19, response categories were assigned a score ranging from 0 to 4 ( 0 = "I do not feel it," 4 = "I feel it intensely"). The obtained values were submitted to a $t$-test for independent samples. Again, the $t$-test confirmed that the two groups did not differ (all ps $>0.14$ ) (Table IV).

As regards the GAD-7 scores, $45.2 \%$ of the respondents showed minimal anxiety (score
$0-4), 34.5 \%$ showed mild anxiety (score 5-10), $13.9 \%$ showed moderate anxiety (score 10-14), while $6.4 \%$ showed a score indicative of a severe level of anxiety (score 15-21). The mean GAD-7 score was $6.04(\mathrm{SD}=4.69)$ for group 1 and 6.19 $(\mathrm{SD}=4.65)$ for group 2. The $t$-test for independent samples showed that the two scores did not differ $(\mathrm{P}=0.64)$.

Dentists have shown a good understanding of what is reported in the most recent indications from the literature regarding the prevention of COVID-19: to the question: "During clinical activity, which measures do you use to prevent COVID-19 infection?" The highest frequency of answers concerned "reduction of number of patients in the waiting room" $(89.1 \%)$ and "environment aeration" (87.8\%). Less frequently, "telephone screening/anamnesis to exclude COVID-19 related symptoms" (84.2\%), "use of PPE" $(76.2 \%)$ or "Disinfectant agents and surgical mask supply to all patients while waiting in waiting room" $(74.1 \%)$ were indicated.

TABLE IV.- - Responses to the question "Which of the following emotions do you feel when thinking about Covid-19?" for the two groups.

\begin{tabular}{|c|c|c|c|c|c|c|}
\hline Emotions & Group & $\begin{array}{c}\text { I do not feel it } \\
\text { N. }(\%)\end{array}$ & $\begin{array}{l}\text { Lightly } \\
\text { N. }(\%)\end{array}$ & $\begin{array}{l}\text { Moderately } \\
\text { N. (\%) }\end{array}$ & $\begin{array}{c}\text { Quite intensely } \\
\text { N. (\%) }\end{array}$ & $\begin{array}{l}\text { Intensely } \\
\text { N. (\%) }\end{array}$ \\
\hline \multirow[t]{2}{*}{ Fear } & 1 & $196(23.7)$ & $311(37.6)$ & $205(24.8)$ & $93(11.2)$ & $23(2.8)$ \\
\hline & 2 & $76(27.0)$ & $107(38.1)$ & $64(22.8)$ & $22(7.8)$ & $12(4.3)$ \\
\hline \multirow[t]{2}{*}{ Anxiety } & 1 & $201(24.3)$ & $276(33.3)$ & $187(22.6)$ & $129(15.6)$ & $35(4.2)$ \\
\hline & 2 & $79(28.1)$ & $91(32.4)$ & $64(22.8)$ & $32(11.4)$ & $15(5.3)$ \\
\hline \multirow[t]{2}{*}{ Concern } & 1 & $42(5.1)$ & $219(26.4)$ & $249(30.1)$ & $202(24.4)$ & $116(14.0)$ \\
\hline & 2 & $11(3.9)$ & 87 (31.0) & 84 (29.9) & $60(21.4)$ & 39 (13.9) \\
\hline \multirow[t]{2}{*}{ Sadness } & 1 & $196(23.7)$ & $182(22.0)$ & $209(25.2)$ & $143(17.3)$ & $98(11.8)$ \\
\hline & 2 & $65(23.1)$ & $67(23.8)$ & $68(24.2)$ & $48(17.1)$ & $33(11.7)$ \\
\hline \multirow[t]{2}{*}{ Anger } & 1 & $337(40.7)$ & $177(21.4)$ & $119(14.4)$ & $94(11.4)$ & $101(12.2)$ \\
\hline & 2 & $103(36.7)$ & 55 (19.6) & $47(16.7)$ & 39 (13.9) & $37(13.2)$ \\
\hline
\end{tabular}

Group 1: responders from Lombardy, Emilia Romagna, Veneto and Piedmont; group 2: all other regions. 


\section{COPYRIGHT $^{\circledR} 2021$ EDIZIONI MINERVA MEDICA}

The answer "body temperature measurement" received the lowest frequency of preferences $(35.3 \%)$. Instead other indications provided by medical organizations and media - "environment sanitation" and "telephone screening/ anamnesis to identify possible critical cases" - received $73 \%$ and $46.8 \%$, respectively. This question could be answered by placing multiple preferences.

We asked the same question at the end of the test, with reference to future behavior, and different percentages emerged: the highest frequency of answers concerned "reduction of number of patients in the waiting room" $(87.8 \%)$ and "use of PPE" (86.5\%), then in descending order "telephone screening/anamnesis to identify possible critical cases" (82.6\%), "environment aeration" (82.6\%), "environment sanitation" (82.5\%), "disinfectant agents and surgical mask supply to all patients while waiting in waiting room" $(71.3 \%)$ and "body temperature measurement" (50.8\%).

We asked the question "Which aids do you think could help dental professionals during COVID-19 pandemic?" Two preferences could be expressed: the respondents indicated "economic relieves from Italian government" (74.4\%), "social security institutions support and subsidy" (47.6\%), "economic relieves from dental associations" (35\%), "improvement of communication with patients" $(18.7 \%)$ and "bank account support" (14.7\%). The answers to the successive question, which analyzes the category aid measures to be adopted after the emergency, maintained almost the same order of frequency in the answers. There was a change in the percentages which, in decreasing order were: "economic relieves from Italian government" (78.1\%), "economic relieves from dental associations" (34.9\%), "social security institutions support and subsidy" (33.6\%), "improvement of communication with patients" $(24.3 \%)$ and "bank account support" (19.5\%). The main change was a significant reduction in "social security institutions support and subsidy" while greater importance was given to communication campaigns with patients and to "bank account support."

The last question asked: "Which improve- ments do you think can result from the COVID-19 emergency?" For this question multiple answers could be indicated. A high percentage of the interviewees considered "prevention procedures standardization" very important $(64.8 \%)$. Most of the dentists answered that there will be a "Professional rhythm slow down" (38.7\%) and "improvement of communication with patients" $(21.3 \%)$. Lower preferences resulted for "stabilization of relationship with dental associations" $(9.7 \%)$ and "reduction of dental practices competition" (6.2\%). $23.3 \%$ of dentists believe that there is no improvement from the Coronavirus emergency.

\section{Discussion}

Health-coworkers have been widely affected by the SARS-CoV-2 pandemic with a dramatic toll, in terms of lives, nationwide.6, 10 Many hypotheses have been made, so far, about the pathogenesis of this new disease, but little is known about its psychological impact on health co-workers in general and on dental practitioners, in particular. The pandemic infection of SARS-CoV-2 is having a profound impact on dentistry, mainly due to the way the pathogen is passed on, which poses a danger in almost all dental procedures. The virus predominantly spreads through droplets and aerosol, requiring a revision of the cross-infection prevention protocol to include SARS-CoV-2 related risks. ${ }^{11}$

Dental practice has been recognized as a necessary service by the Italian Prime Minister's Decree of March 22, 2020 and its update on March 25, 2020,12 but isolation and its financial impact have produced physical and psychological pressure, depression, social anxiety or other mental health concerns among dental practitioners. The aim of this study was to measure the impact of this turmoil on dentists in Italy, one of the most involved nations in the COVID-19 outbreak in Europe and, perhaps, worldwide. The questionnaire was designed in the Italian language and enclosed questions pertaining to socio-demographic characteristics, dentists' attitudes and perceptions toward COVID-19 and infection control in dental clinics. The survey emphasized the psychological impact on our profes- 


\section{COPYRIGHT $^{\circledR} 2021$ EDIZIONI MINERVA MEDICA}

sion and provided insight into whether dentists in Italy have made any changes in their routine dental treatment practices since the COVID-19 pandemic started.

In a previous survey, severe levels of anxiety have been reported by $9 \%$ of the 356 interviewed dentists, demonstrating that COVID-19 emergency had a highly negative impact on their psychological wellness. ${ }^{7}$ All of the respondents closed or highly reduced their activity to urgent procedures. For $74.4 \%$ of the respondents, COVID-19 was having a highly negative impact on their occupation and the majority of them $(89.6 \%)$ was quite concerned about their professional future. In addition, $20.2 \%$ were extremely worried about contracting COVID-19 during their clinical activity while $2.2 \%$ were not concerned at all. ${ }^{7}$

Other investigations have been proposed by other international institutions, targeting the aftermath of this new pandemic on dental professionals. One inquiry was performed in Saudi Arabia, with a more global reach: 650 dentists spread out in many countries, mostly in Pakistan, India and Malaysia, where the dental setting might differ from Western standards and where the majority of the colleagues are employed in public settings. ${ }^{13}$

Another analysis was conducted among Turkish dentists. ${ }^{14}$ The results of the survey revealed that, although some have increased protective measures against the COVID-19 pandemic, the majority have not reached sufficient levels of awareness in terms of attitudes and behaviors, since $26 \%$ of them reported no changes in their practice in terms of new prophylactic measures for COVID-19 prevention and only $18.6 \%$ have partially reduced the number of patient's admission. Surprisingly, only $1.35 \%$ of them was concerned about being infected by the SARS$\mathrm{CoV}-2 .{ }^{14}$

Measuring anxiety by the means of self-report questionnaires is useful 15 and has been already

performed among dental practitioners and patients. ${ }^{16}$ Moreover, the interest for the psychological impact of a sanitary crisis among health care workers is not new. Previous researches conduced in Europe, Asia and North America, on H1N1 flu and SARS-CoV-1 epi- demic, have shown moderate to severe level of anxiety among physicians with a markedly increased risk for psychiatric morbidity among the most exposed categories of health professionals. ${ }^{17,} 18$ The most commonly reported psychiatric symptoms have been related to the post-traumatic stress disorder (PTSD) with risk factor being the absence of psychological consult, older age, social isolation, social stigmatization and high level of stress at the working place. Interestingly, this post-traumatic psychiatric condition can arise even in the long term, on average after 1 to 2 years after exposure to the traumatic event. ${ }^{19}$

The way this SARS-CoV-19 pandemic has rapidly spread out, its severity, the high mortality rate among health care workers and the lack of knowledge have raised the psychological burden among dentists. Moreover, the need for new and more restrictive working protocols, the fear for a global economic crisis, the inadequacy of economic aids from the national government have probably boosted the level of fear and anxiety toward the future of our profession.

The literature reports that approximately four in five patients are asymptomatic, demonstrating the importance of preventive measures regardless of patients' clinical conditions. ${ }^{20}$ Italy is now in the so called "phase-two" of the restrictive measures enforced by the national government, being the incidence of daily new cases very low and probably at its minimum rate since the beginning of the pandemic. The Italian health care system is no longer overwhelmed by new COVID-19 cases and the critical phase seems to be overstepped. Dentists are now treating not only emergency patients but are also performing those elective procedures that have been postponed for months, during the outburst of the pandemic. However, the preventive measures, previously recommended by the national dental institutions, are generally still held valid. Four phases are considered crucial in patient management: patient triage, patients' entrance into the practice, dental treatment, and after-treatment management. ${ }^{6}$ Patients should be asked a set of questions aimed at evaluating the risk of exposure to SARS-CoV-2 and should be admitted to the dental office only if the entire questionnaire 


\section{COPYRIGHT $^{\circledR} 2021$ EDIZIONI MINERVA MEDICA}

is negative; otherwise, the appointment must be postponed. ${ }^{2}$ Moreover, body temperature has to be registered through a contactless thermometer and hand disinfection encouraged before entering the operative area. ${ }^{2,3}$ A patient restriction is also recommended in the waiting room with a suggested distance of at least 1 meter between chairs. Accompanying subjects should be asked to wait outside the dental office in order to prevent overcrowding. ${ }^{2-4}$ Dental practitioners should perform thorough hand washing for at least $60 \mathrm{~s}$, employing a hydro-alcoholic solution, prior to wearing gloves. ${ }^{2}$ Highly filtering face masks (filtering face - piece level 2 or 3) should be worn by the whole team, including nonclinical staff members and eye protection should be guaranteed with the use of protective safety glasses and shields, which should undergo thorough disinfection with $70 \%$ isopropyl after each procedure..$^{2-4}$ A 5-10 min air exchange is advised in between patients. $.^{2-4} \mathrm{De}-$ spite these recommendations, the fear of contagion among dental practitioners and patients is still high, although the mortality rate is $2-3 \%$. Its prevention has brought serious consequences to the global economy with catastrophic results for many small- and middle-sized businesses. In most of countries affected by COVID-19, Italy being one of them, dental practices are predominantly small to medium-sized business operated privately. The longer restrictive measures are extended, the more likely they seem to affect the economic capacity of dental practices, which may translate into job losses and qualitative and quantitative changes in care provision. ${ }^{21}$

\section{Conclusions}

The COVID-19-related emergency condition had a highly negative impact on dental practices in Italy. All of the dentists that completed the survey reported practice closure or reduction during the lockdown, a high level of concern about the professional future for all dental practitioners. Concerns related to professional activity were accompanied by severe anxiety levels. This essay must be contextualized with the lockdown in Italy, since it was delivered during the most critical period of the pandemic.

\section{References}

1. Peng X, Xu X, Li Y, Cheng L, Zhou X, Ren B. Transmission routes of 2019-nCoV and controls in dental practice. Int J Oral Sci 2020;12:9.

2. Checchi V, Bellini P, Bencivenni D, Consolo U. COVID-19 dentistry-related aspects: a literature overview. Int Dent J 2020. [Epub ahead of print]

3. Lo Giudice R. The Severe Acute Respiratory Syndrome Coronavirus-2 (SARS CoV-2) in Dentistry. Management of Biological Risk in Dental Practice. Int J Environ Res Public Health 2020;17:3067.

4. Consolo U, Bencivenni D, Checchi V, Bellini P. COVID-19 and dentistry: a new challenge. Dent Cadmos 2020;88:344-52.

5. WHO health emergency dashboard. World Health Organization; 2020 [Internet]. Available from: https://covid19.who. int/region/euro/country/it [cited 2020, Oct 22].

6. Izzetti R, Nisi M, Gabriele M, Graziani F. COVID-19 Transmission in Dental Practice: Brief Review of Preventive Measures in Italy. J Dent Res 2020;99:1030-8.

7. Consolo U, Bellini P, Bencivenni D, Iani C, Checchi V. Epidemiological Aspects and Psychological Reactions to COVID-19 of Dental Practitioners in the Northern Italy Districts of Modena and Reggio Emilia. Int J Environ Res Public Health 2020;17:3459.

8. Spitzer RL, Kroenke K, Williams JB, Löwe B. A brief measure for assessing generalized anxiety disorder: the GAD-7. Arch Intern Med 2006;166:1092-7.

9. COVID-19 - Situazione in Italia. Ministero della Salute; 2020 [Internet]. Available from: http://www.salute.gov.it/ portale/nuovoCoronavirus/dettaglioContenutiNuovoCoronavirus.jsp? area $=$ nuovoCoronavirus $\& i d=5351 \&$ lingua $=$ italian o\&menu=vuoto [cited 2020, Apr 29].

10. Elenco dei Medici caduti nel corso dell'epidemia di COVID-19. Federazione Nazionale degli Ordini dei Medici Chirurghi e degli Odontoiatri; 2020 [Internet]. Available from: https://portale.fnomceo.it/elenco-dei-medici-cadutinel-corso-dellepidemia-di-covid-19/ [cited 2020, oct 22].

11. Coronavirus situation report-83. World Health Organization; 2020 [Internet]. Available from: https://apps.who.int/ iris/handle/10665/331781 [cited 2020, Oct 22].

12. Coronavirus, firmato il Dpcm 22 marzo 2020. Governo italiano, Presidenza dei Ministri; 2020 [Internet]. Available from: http://www.governo.it/it/articolo/Coronavirus-firmatoil-dpcm-22-marzo-2020/14363 [cited 2020, Oct 22].

13. Ahmed MA, Jouhar R, Ahmed N, Adnan S, Aftab M, Zafar MS, et al. Fear and practice modifications among dentists to combat Novel Coronavirus Disease (COVID-19) outbreak. Int J Environ Res Public Health 2020;17:E2821.

14. Duruk G, Gümüşboğa ZS, Çolak C. Investigation of Turkish dentists' clinical attitudes and behaviors towards the COVID-19 pandemic: a survey study. Braz Oral Res 2020;34:e054.

15. Bellini M, Maltoni O, Gatto MR, Pelliccioni G, Checchi $\mathrm{V}$, Checchi L. Dental phobia in dentistry patients. Minerva Stomatol 2008;57:485-95.

16. Bellini M, Marini I, Checchi V, Pelliccioni GA, Gatto MR. Self-assessed bruxism and phobic symptomatology. Minerva Stomatol 2011;60:93-103.

17. Tam CW, Pang EP, Lam LC, Chiu HF. Severe acute respiratory syndrome (SARS) in Hong Kong in 2003: stress and psychological impact among frontline healthcare workers. Psychol Med 2004;34:1197-204. 


\section{COPYRIGHT $^{\odot} 2021$ EDIZIONI MINERVA MEDICA}

18. El-Hage W, Hingray $C$, Lemogne $C$, Yrondi A, Brunault $\mathrm{P}$, Bienvenu $\mathrm{T}$, et al. [Health professionals facing the coronavirus disease 2019 (COVID-19) pandemic: what are the mental health risks?]. Encephale 2020;46:S73-80. French.

19. Maunder RG, Lancee WJ, Balderson KE, Bennett JP, Borgundvaag B, Evans S, et al. Long-term psychological and occupational effects of providing hospital healthcare during SARS outbreak. Emerg Infect Dis 2006;12:1924-32.

20. Day M. Covid-19: four fifths of cases are asymptomatic, China figures indicate. BMJ 2020;369:m1375.

21. Schwendicke F, Krois J, Gomez J. Impact of SARSCoV2 (Covid-19) on dental practices: economic analysis. J Dent 2020;99:103387.

Conflicts of interest.-The authors certify that there is no conflict of interest with any financial organization regarding the material discussed in the manuscript.

Authors' contributions.-All authors read and approved the final version of the manuscript.

History.-Article first published online: September 22, 2020. - Manuscript accepted: September 9, 2020. - Manuscript received: August 2, 2020. 